\title{
Evolution of the dry zone water harvesting and management systems in Sri Lanka during the Anuradhapura Kingdom; a study based on ancient chronicles and lithic inscriptions
}

\author{
Nuwan Abeywardana ${ }^{1}$ (D) H. M. T. G. A. Pitawala ${ }^{2} \cdot$ Brigitta Schütt $^{1}$ • \\ Wiebke Bebermeier ${ }^{1}$
}

Received: 5 October 2018 / Accepted: 4 June 2019 / Published online: 3 July 2019

(C) The Author(s) 2019

\begin{abstract}
A significant number of written sources report on the development of ancient dry zone water harvesting and water management systems in Sri Lanka. This paper attempts to address the lack of a systematic assessment of the information given by sources on the spatial-temporal development of the system, using methods of source criticism. After the removal of double entries, 255 text passages containing 837 different records on ancient irrigation were compiled as a database for the period from the fifth century BCE to the tenth century CE. The majority of the 625 analyzed records were derived from inscriptions, 212 records originated from chronicles. Geocoding was successfully performed for 40 records. It was possible to link 173 text passages to a specific king's reign. Altogether 362 records $(43.2 \%)$ mention a tank or its construction. The categories "grants of irrigation" and "irrigation incomes" are represented with 276 records (33\%) and 75 records (9\%). Records on canals and irrigation management occur with a share of $8.2 \%$ and $6.2 \%$, equaling 69 and 52 records. The spatial distribution of records in general largely corresponds to the extent of the Dry Zone and northern intermediate zone. With 490 records, Anuradhapura district shows the highest density of information on the ancient water harvesting and management system. The analyzed data are not equally distributed throughout the investigated period and show a distinct peak in the second century CE. In conclusion, the conducted analysis documents the potential of the analyzed source genres for the derivation of information on different aspects related to the spatial, temporal and administrative development of the ancient water management system in Sri Lanka.
\end{abstract}

Keywords Environmental history · Tank cascade system $\cdot$ Sustainability

Nuwan Abeywardana

nuwan@zedat.fu-berlin.de; nuwanabeywardana@yahoo.com

Extended author information available on the last page of the article 


\section{Introduction}

The beginning of the Historic epoch in Sri Lanka is dated to the fourth century BCE (Coningham 2013). From this time a remarkable number of written sources give witness to different facets of socio-political, socio-economic and religious developments and events (Ray 1960). Rock inscriptions, originating from the third century BCE, represent the earliest category of comprehensive written evidence on the island, while the written chronicles of Sri Lanka the Dipavamsa, Mahavamsa, and the Culawamsa were written from the fourth century CE onwards, but also report retrospectively on earlier centuries (Geiger 1930).

Numerous of the written and epigraphic sources address aspects related to the ancient water harvesting and water management systems implemented in the Dry Zone of Sri Lanka, c. 2000 years ago. The Dry Zone spreads north, east and south of the central highlands and corresponds predominantly to the present day North Central Province (Fig. 1). Climatically, the North Central Province fit into the seasonal dry tropics (Sakthivadivel et al. 1996) and is characterized by seasonally limited water availability (Jayasena et al. 2011). Mean annual precipitation averages around $1750 \mathrm{~mm}$, while annual evaporation totals $1290 \mathrm{~mm}$ (Panabokke 2002), leading to water deficit especially during the summer months. The water harvesting and water management systems are composed of a series of human-made reservoirs, locally called wewa, constructed cascade-like along shallow river valleys (Madduma Bandara 1995). The tanks are connected by channels and spillways and allow water to be conveyed along the cascade and to irrigate interconnected agricultural fields. According to the ancient text sources, this tank-based irrigation system was initiated in the fourth/third century BCE and had its maximum extent in the twelfth century CE (Abeywardana et al. 2018). Up to 10,000 of the tanks in use today were installed during antiquity, clearly documenting their significance and sustainability (Dahdouh-Guebas et al. 2005). The land use of the North Central Province is composed of irrigated paddy cultivation in tank command areas, rain-fed "slash and burn"/shifting cultivation (chena) in the forested uplands, and perennial crops in home gardens using sub-surface moisture (Abeywardana et al. 2019).

A systematic analysis of the information provided by the epigraphic and written sources about the water harvesting and water management systems has not yet been carried out, although researchers have shown awareness of the potential of these systems. Brohier was one of the first scholars to acknowledge the importance and history of Sri Lanka's ancient irrigation works (Brohier 1979, 1935). His great achievement was linking selected tanks mentioned in the chronicles to major present-day irrigation works. In 1961 Leach published a landmark study on a traditional village irrigation system in Pul Eliya, North Central Sri Lanka. In more recent times various scholars such as Madduma Bandara (1985), Ithakura and Abernethy (1993), Panabokke et al. (1999) and Tennakoon (2001) investigated the physical characteristics, environmental perspectives, and techno-engineering aspects of these systems. Tank sediments as archives for environmental reconstruction were investigated by Schütt et al. (2013) and Bebermeier et al. (2017). Withanachchi (2013, 2014) investigated Sri Lanka's water management systems from a historical perspective with special reference to ancient anicuts and dams.

This paper systematically assesses the information given by epigraphic and written sources on the spatio-temporal development of the tank-cascade systems in Sri Lanka. Thereby, the focus is on distinct source criticism, culminating in an analysis of the usability of these source genres for the deduction of information on early irrigation management in Sri Lanka. 


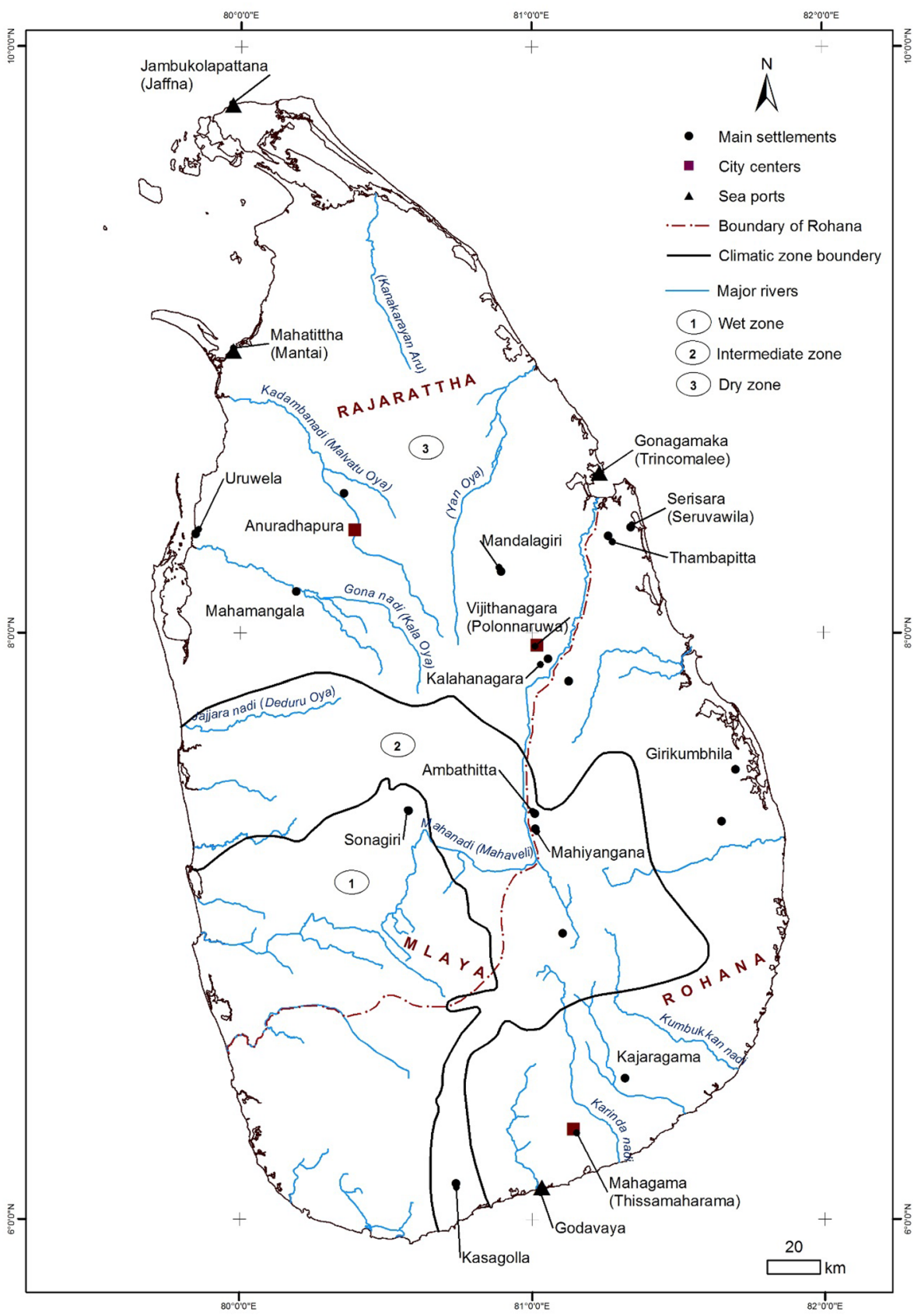

Fig. 1 Administrative centers of Sri Lanka during the Middle Historic period (c.300-1250 CE) and presentday climatic zones. Sources river courses are based on survey department 1:250,000 topo sheets, climatic zones are based on National Atlas of Sri Lanka (Somasekaram et al. 1988), historical place names and administrative units are derived from Liyanagamage and Gunavardhana (1965) 


\section{Materials and methods}

Different written and epigraphic sources report on the historical past of Sri Lanka (Ray 1960). Unknown authors finished the Dipavamsa, the first written chronicle of the island, in the middle of the fourth century CE. It describes the history of the country until the end of the reign of King Mahasen in 362 CE (Ray 1960). Originally written in Pali verse, H. Oldenberg translated The Dipavamsa into English (Oldenberg 1879). The second comprehensive chronicle considered in this study is the Mahavamsa-"the Great Chronicle" of Sri Lanka, which was also written in Pali and translated by Geiger into German (Geiger 1908). The Mahavamsa is structured in two main sections: the Mahavamsa (the Great Chronicle) and the Culavamsa (the Little Chronicle) (Geiger 1930). According to Geiger (1930), the whole chronicle consists of four different parts:

- The Mahavamsa was compiled by the Buddhist monk Mahanama (fourth or sixth century CE) and encompasses Chapters 1 to Chapter 37, Verse 50, covering the period 544 BCE-362 CE.

- The Culavamsa, Part 1 was compiled by the Buddhist monk Dhammakitti (twelfth century CE) and encompasses Chapter 37, Verse 51 to Chapter 79, Verse 84, reporting on the period $362 \mathrm{CE}-1186 \mathrm{CE}$.

- The Culavamsa, Part II was compiled by an unknown author and comprises Chapter 79, Verse 85 to Chapter 90, Verse 102; it contains information for the period 11861333 CE.

- The Culavamsa, Part III was compiled by the Buddhist monk Tibbotuvave Sumangala in the eighteenth century CE and encompasses Chapter 90, Verse 105 to Chapter 100, Verse 292, reporting on the period 1333-1781 CE.

When assessing the Mahavamsa as a document reporting historical events, it has to be noted that the texts include numerous legendary and mythological incidents as well as literary ornamentation (Adithiya 1984). Records selected for the database were carefully analyzed to filter out only events with a historical kernel related to ancient irrigation landscapes or water management systems. In cases where two sources report the same event, the source chronologically closest to the event was considered in the database. In cases where the Dipavamsa and the Mahavamsa repeat the same information, entries from the Mahavamsa were considered since the Mahavamsa is regarded as the more complete and trustworthy source (Adithiya 1984; Geiger 1930).

Secondly, the lithic inscriptions originating from the third century BCE onwards were systematically analyzed to derive additional information not provided by the chronicles and to crosscheck information recorded in the chronicles. From the third century BCE to the seventh century CE these inscriptions were written in Brahmi script and are categorized in cave, rock, pillar and slab inscriptions (Dias 2001). Paleographically, Brahmi texts are divided into three major categories (according to Dias 2001):

- Early Brahmi (third century BCE-first century CE)

- Late Brahmi (second century CE-fourth century CE)

- Transitional Brahmi (fifth century CE-seventh century CE)

From the eighth century $\mathrm{CE}$ onwards most rock inscriptions were written in early Sinhalese script. The inscriptions predominantly address common acts such as grants of 
cave-dwellings, monasteries, land, tanks and villages as well as revenues from the tanks and lands (Dias 2001). Further, they contain details on bureaucracy, as they were used to publish rules and regulations for the management of the landscape (Dias 2001). The following compilations of ancient Sri Lankan inscriptions (translated into English) were systematically analyzed:

- Inscriptions of Ceylon Volume I (Paranavithana 1970)

- Inscription of Ceylon Volume II, Part 01 (Paranavitana 1983)

- Inscription of Ceylon (IC) Volume II, Part 02 (Paranavitana 2001)

- Inscription of Ceylon Volume V, Part 01 (Ranawella 2001)

- Inscription of Ceylon Volume V, Part 02 (Ranawella 2004)

- Inscription of Ceylon Volume V, Part 03 (Ranawella 2005)

- Epigraphia Zeylanica (EZ) Volume I (de Silva Wicremasinghe 1912)

- Epigraphia Zeylanica Volume II (Wickremasinghe 1928)

- Epigraphia Zeylanica Volume III (Wickremasinghe and Codrington 1933)

- Epigraphia Zeylanica Volume IV (Codrington and Paranavitana 1934)

- Epigraphia Zeylanica Volume V, Part 01 (Paranavitana 1955)

- Epigraphia Zeylanica Volume V, Part 02 (Paranavitana and Godakumbura 1963)

- Epigraphia Zeylanica Volume V, Part 03 (Paranavitana and Godakumbura 1965)

- Epigraphia Zeylanica Volume VI (Paranavitana et al. 1973)

- Epigraphia Zeylanica Volume VII (Saddhamangala 1984)

- Epigraphical Notes (EN) 1-18 (Dias 1991)

- Inscriptions Volume II (Wijesekara 1990)

Records from the chronicles and lithic inscriptions of the Anuradhapura period were analyzed and relevant text passages were extracted and integrated in a database. Subsequently, each text item was assigned to one of the following categories: (i) laws and official announcements, (ii) irrigation taxes, shares and income, (iii) grants of irrigation works, (iv) canals, (v) tanks, ponds, dams and water holes, (vi) others.

If feasible, single records were geocoded and chronologically assigned to a ruler. Exact geocoding was realized by linking locational names given in the sources to present-day settlements or landmarks. Some other scholars have already conducted some parts of this task; in such cases, the relevant literature was cited. If direct geocoding could not be performed, texts from inscriptions were geocoded based on the place of their composition. Geocoded information was integrated to a GIS (ArcMap 10.4.1) and assigned to present-day district boundaries which serve as spatial entities for the presentation of geocoded results, as a delineation of the respective territories is challenging (Fig. 2). Since no data are available to demarcate the extent of the hinterland of Anuradhapura, present-day administrative boundaries are used to represent this area. Descriptive statistical analyses were performed to analyze information on the spatial and temporal distribution of the text items.

\section{Results}

In total, 275 text passages containing 934 different records on ancient irrigation activities were compiled for the period between the fifth century BCE and the tenth century CE. After removal of double entries 255 text passages and 837 records remained, the spatial and temporal distribution of which are presented in this paper following a short general 

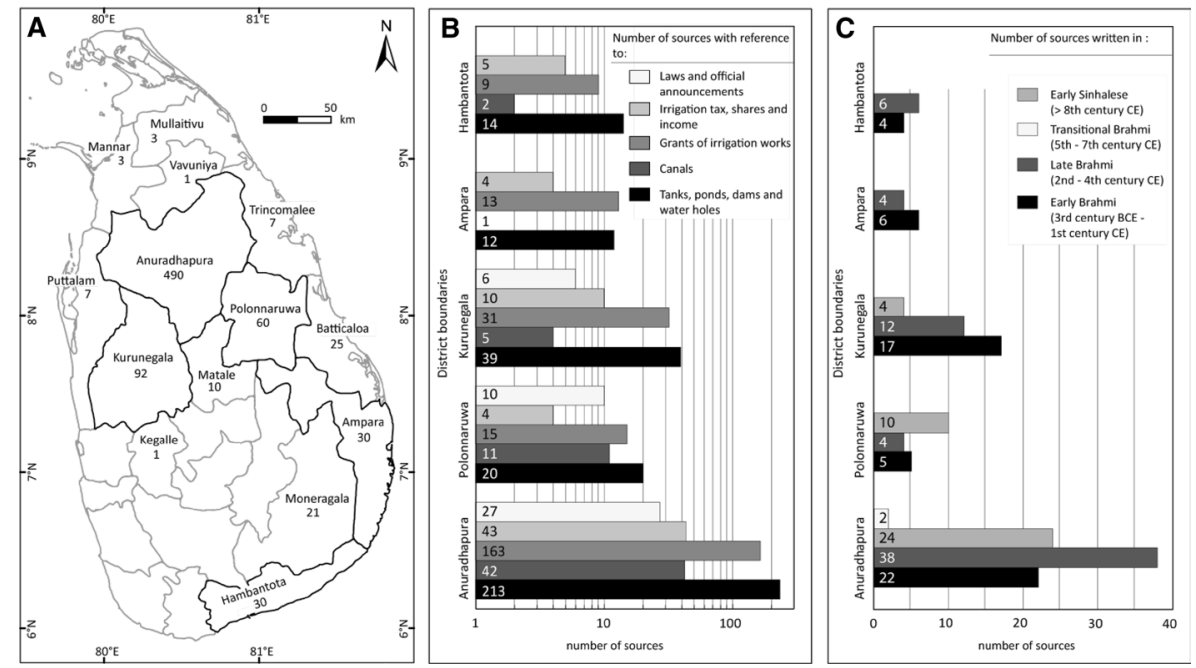

Fig. 2 Spatial distribution of records in Sri Lanka based on present-day district boundaries. a Present-day district boundaries, districts with black contour lines are characterized by $\geq 30$ records on water harvesting and water management systems, districts with grey boundaries contain $<30$ records on water harvesting and water management systems, black numbers in a indicate the sum of records for each district. b Detailed breakdown of analyzed categories for districts with $\geq 30$ records. $\mathbf{c}$ Number of analyzed inscriptions; in sum 57 sources could not be linked to a district

overview of the overall database. Geocoding was successfully performed for 40 records and 173 text passages could be chronologically linked to a specific king's reign.

The majority of the 625 records analyzed are based on ancient inscriptions. 131 records originate from the Chulavamsa and 80 records from the Mahavamsa. Due to double entries, only one record was extracted from the Dipavamsa (Table 1).

Concerning the source genre of inscriptions, the script functioned as a proxy to link the texts to a certain period. The largest proportion of records were derived from inscriptions in Late Brahmi script $(n=330)$, which was used between the second century CE and the fourth century CE. Another 200 records refer to sources in Early Brahmi script (third century BCE-first century CE) and 23 records refer to Transitional Brahmi sources (fifth-seventh century CE). Another 72 records are assigned to

Table 1 Distribution of analyzed records

\begin{tabular}{|c|c|c|c|c|c|c|c|c|c|c|c|c|c|c|}
\hline \multirow[t]{2}{*}{ Source } & \multicolumn{2}{|c|}{$\begin{array}{l}\text { Tanks, } \\
\text { ponds and } \\
\text { dams and } \\
\text { water holes }\end{array}$} & \multicolumn{2}{|c|}{ Canals } & \multicolumn{2}{|c|}{$\begin{array}{l}\text { Grants of } \\
\text { irrigation } \\
\text { works }\end{array}$} & \multicolumn{2}{|c|}{$\begin{array}{l}\text { Irriga- } \\
\text { tion tax, } \\
\text { shares and } \\
\text { income }\end{array}$} & \multicolumn{2}{|c|}{$\begin{array}{l}\text { Laws and } \\
\text { official } \\
\text { announce- } \\
\text { ments }\end{array}$} & \multicolumn{2}{|c|}{$\begin{array}{l}\text { Other } \\
\text { aspects }\end{array}$} & \multicolumn{2}{|c|}{ Sum } \\
\hline & No & $\%$ & No & $\%$ & No & $\%$ & No & $\%$ & No & $\%$ & No & $\%$ & No & $\%$ \\
\hline Inscriptions & 231 & 64 & 44 & 64 & 226 & 82 & 71 & 95 & 51 & 98 & 2 & 67 & 625 & 75 \\
\hline Culavamsa & 70 & 19 & 10 & 14 & 46 & 17 & 3 & 4 & 1 & 2 & 1 & 33 & 131 & 15 \\
\hline Mahavamsa & 60 & 17 & 15 & 22 & 4 & 1 & 1 & 1 & 0 & 0 & 0 & 0 & 80 & 10 \\
\hline Dipavamsa & 1 & 0 & 0 & 0 & 0 & 0 & 0 & 0 & 0 & 0 & 0 & 0 & 1 & 0 \\
\hline Sum & 362 & 100 & 69 & 100 & 276 & 100 & 75 & 100 & 52 & 100 & 3 & 100 & 837 & 100 \\
\hline
\end{tabular}


early Singhalese scripts, which date to the period between the eighth century CE and the tenth century CE.

Altogether 362 records (43\%) mention a tank or a pond, dam or water holes or their construction (Table 1). The categories "grants of irrigation" occur in 276 records (33\%) and "irrigation income" in 75 records (9\%). Records on canals account for a share of $8 \%$ and records on laws/official announcements 6\%, i.e. 69 and 52 records respectively. The category of other aspects related to irrigation includes three records and thus can be omitted (Table 1).

In the chronicles different terminologies were used for the term tank: gamikavavi (village tanks), mahavavi (large tanks) and danavavi (feeder tanks). Water holes and ponds are represented as kumi and pokkarani in the inscriptions while chronicles mentioned them as jathasara and pokkarani. Revenue for water is referred to as udabhaga in the chronicles, while in inscriptions frequently the terms dakapati or bojaka-pati are used. The chronicles name canals as matika and dakawara, in contrast lithic inscriptions mention them as adi, ali or ala. Selected examples from the database will serve to document the variety of the information compiled:

Tanks, ponds, dams and water holes

Then nearing Anuradhapura the king pitched his camp south of the Kasa-mountain. When he had made a tank there in the month Jetthamula he held a waterfestival. (Mahavamsa 25/50-51).

\section{Canals}

(...) Agriculture officers and perenattiyam [undefined profession] shall not enter;

(...) the water flowing from the main canal to this village shall not be hindered; (...) (IC 5, Part 1, 94.4).

\section{Grants of irrigation works}

When the king had made the Gamanitissa-tank he bestowed it on the Abhayagiri vihara [monastery] for maintenance in food (Mahavamsa 35/120).

Irrigation tax, shares and income

Success! The water revenue and the overlord's revenue of the tank of Nakava in Mayihina, King Naga donated to the Community of bhikkhus [monks] (IC 2, Part $1,74)$

\section{Laws and official announcements}

(...) set up four pillars at the four corners (of the Abhayavava) in order to safeguard (the said) Abhayavava, and decreed that if the Nuvaraladda [the City Mayor] fails to keep a watch, arrest, (charge) and punish those who may engage in (illegal) fishing in the Abhayavava, the Madabi Officer [undefined profession], who takes care of the property of the Mahavihara, shall impose and collect a fine of ten hunas of gold from him; also, after having sent his own monastic officials, he shall confiscate the fishing nets of the culprits; and (in addition) get them to perform (free) labor at this reservoir. Those fishermen who are arrested after keeping a watch at the fishing point of this reservoir (IC V, Part 1/10.5). 


\section{Spatial distribution of records on water harvesting and water management systems during the period of the Anuradhapura Kingdom 377 BCE-1017 CE}

The spatial distribution of the 625 records on water harvesting and management systems generally matches with the extension of the Dry Zone and northern Intermediate Zone of Sri Lanka (Fig. 1). Only for the present-day district of Jaffna, located in the north of the Dry Zone, are no records available. The same applies to the Wet Zone, located in the south-west of the island.

With 490 records, the present-day district of Anuradhapura shows the highest density of information on ancient water harvesting and water management systems, followed by the district of Kurunagala with 92 records and Polonnaruwa with 60 records (Fig. 2a). The districts of Ampara and Hambantota within the limits of the ancient Rohana Kingdom are each represented by 30 records. Less than 30 records document ancient water harvesting and management systems in all other districts.

Records on tanks make up the largest category of written sources in the districts of Anuradhapura, Polonnaruwa, Kurunegala, and Hambantota, followed by records on grants of irrigation works (Fig. 2b). In the district of Ampara, records on grants of irrigation works occur more frequently than records on tanks. For the district of Polonnaruwa located in the north-central area of the Dry Zone, records on canals are the third most abundant category related to ancient water harvesting and management systems. In contrast, in the districts Anuradhapura, Ampara and Hambantota, records on irrigation tax, shares and income make up the third most abundant category. There are no records on laws and official announcements in two districts located in the south-east to south of Sri Lanka (Fig. 2b).

The occurrence of scripts does not follow a uniform spatial distribution (Fig. 2c). While Early Brahmi and Late Brahmi scripts occur in all districts, inscriptions written in Early Sinhalese and Transitional Brahmi were not found in the districts of Ampara and Hambantota. Only two Transitional Brahmi inscriptions captured in the database are linked to the district of Anuradhapura.

\section{Temporal distribution of records on water harvesting and management systems during the period of the Anuradhapura Kingdom 377 BCE-1017 CE}

Records on ancient water harvesting and management systems are not equally distributed throughout the study period (fifth century BCE to tenth century CE) (Fig. 3a). Between the fifth and third centuries BCE there are less than five records in each century. Progressing through until the first century CE (Fig. 3a) the number of records slightly increases to a peak in the second century CE with 313 records. The subsequent centuries do not show a clear trend: in the third, fifth and tenth centuries CE the number of records is over 50, while in the intermediate centuries the number of records is considerably lower with values ranging between 36 records in the sixth century $\mathrm{CE}$ and five records in the eighth century CE.

For the present-day district of Anuradhapura the total number of records on water harvesting and water management systems generally follows a course comparable to that of the records of the whole dataset (Fig. 3a). Between the fifth and third centuries BCE all records are related to the district of Anuradhapura while in the first century CE the share of records from Anuradhapura reaches a low point of $25 \%$; for the whole investigation period an average of $62.8 \%$ of records relate to Anuradhapura and its hinterland. 

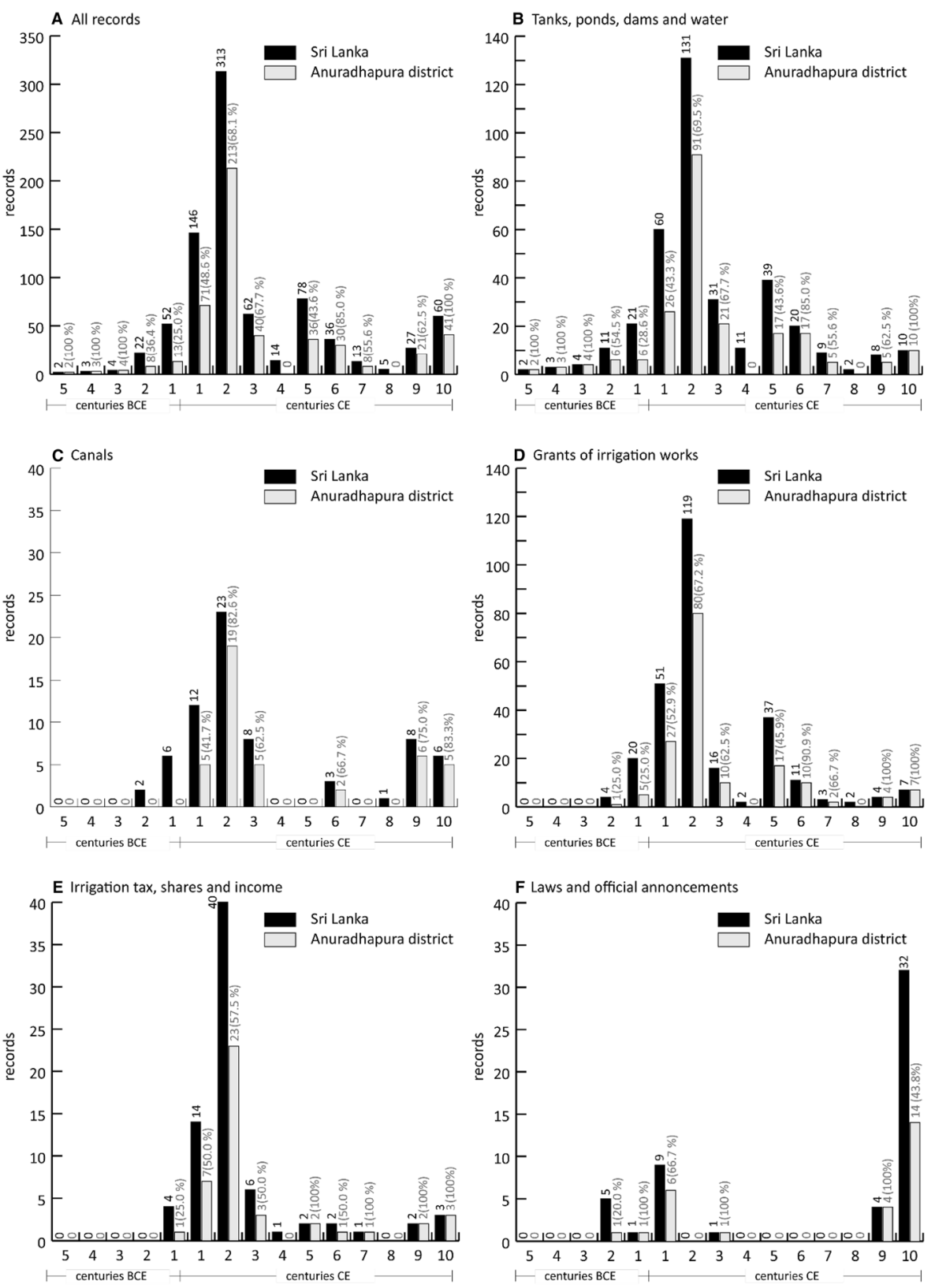

Fig. 3 Temporal distribution of records on ancient water harvesting and water management systems for Sri Lanka and the present-day district of Anuradhapura

The category "tanks, ponds, dams and water holes" $(n=362)$ is that with the earliest available information on ancient water harvesting and water management systems, dating from the fifth century BCE (Fig. 3b). The dataset peaks with 131 records in the second century $\mathrm{CE}$, while the following centuries are characterized by considerably fewer 
references. The district of Anuradhapura holds an average share of $65 \%$ of the overall dataset $(\mathrm{STD}=29.3, \mathrm{n}=213)$. Records for the district of Anuradhapura run parallel to the overall dataset with a peak of 91 items for the second century CE. In contrast, no records are available for the fourth and eighth centuries CE.

Records on canals $(n=69)$ appear first in the second century BCE in inscriptions and peak with 23 records in the second century CE after a steady increase (Fig. 3c). The first time a canal is mentioned in a chronicle dates to the reign of King Kutakannathiss (reign: 42-20 BCE) (Mahavamsa XXXIV/32, Dipavamsa XVI/61). After the second century CE data on canals are scarce and are completely non-existent in the fourth, fifth and seventh centuries CE. In the last two hundred years of the study period the number of records on canals increases again to eight, respectively six records. The onset of records on canals in the district of Anuradhapura dates to the first century CE and in the subsequent centuries parallels the course of the overall database records on canals. On average $51.5 \%$ of all records on canals originate from the Anuradhapura district $(\mathrm{STD}=32.2, \mathrm{n}=42)$.

The earliest record in the category relating to grants of irrigation works $(n=276)$ dates from the second century BCE with numbers of records increasing in the subsequent centuries, peaking in the second century CE with 119 records (Fig. 3d). For the third century CE 16 records are available, before the number decreases to two records in the fourth century CE. After a renewed rise in the fifth century with 37 records on grants of irrigation works, the number of records decreases in the following centuries to values below 10. Between the second century BCE and the third century BCE, the number of records on grants of irrigation works available for the hinterland of Anuradhapura runs parallel to the number of the records of the whole dataset. For the fourth century there are no records available for Anuradhapura, while in the subsequent centuries records on grants of irrigation works again increase in importance, in the district of Anuradhapura as well as for the whole of Sri Lanka. The hinterland of Anuradhapura accounts for an average of $57.8 \%$ of the overall database records on grants of irrigation works $(\mathrm{STD}=30.9, \mathrm{n}=163)$.

Records on laws and official announcements related to the ancient water harvesting and water management systems $(n=52)$ started in the second century BCE (Fig. 3f). Records of this category do not show entries between the fourth and eighth centuries CE, and peak with 32 records in the tenth century. The Anuradhapura district holds an average share of $71.7 \%$ of total database records in this category $(\mathrm{STD}=31.3, \mathrm{n}=27)$. For the first, third and ninth centuries $\mathrm{CE}$ all database records are allocated to the Anuradhapura district.

\section{Information derived from records on the development of water harvesting and water management systems}

\section{Tanks}

Numerous recent large and medium-sized tanks in the hinterland of Anuradhapura were mentioned in the 837 text records registered. Scholars like Brohier (1997), Gunawardana (1971) and Parker (1909) succeeded in linking ancient tank names to modern irrigation construction works. Combining this information with the geo-coded database records, the first documentation of selected tanks in written sources is shown in Figs. 4 and 5. The first recognizable tank in Anuradhapura-Abhayavapi-was constructed by King Pandukabhaya (reign: 437-367 BCE) and is identical to the present-day Basawakkulama tank (Parker 1909; Ranawella 2001; Mahavamsa X/84-88, IC, V. part 1. No 10.5) (Fig. 4, number 1; Fig. 5g). The same king also created the Gamanivapi tank which Parker (1909) succeeded 


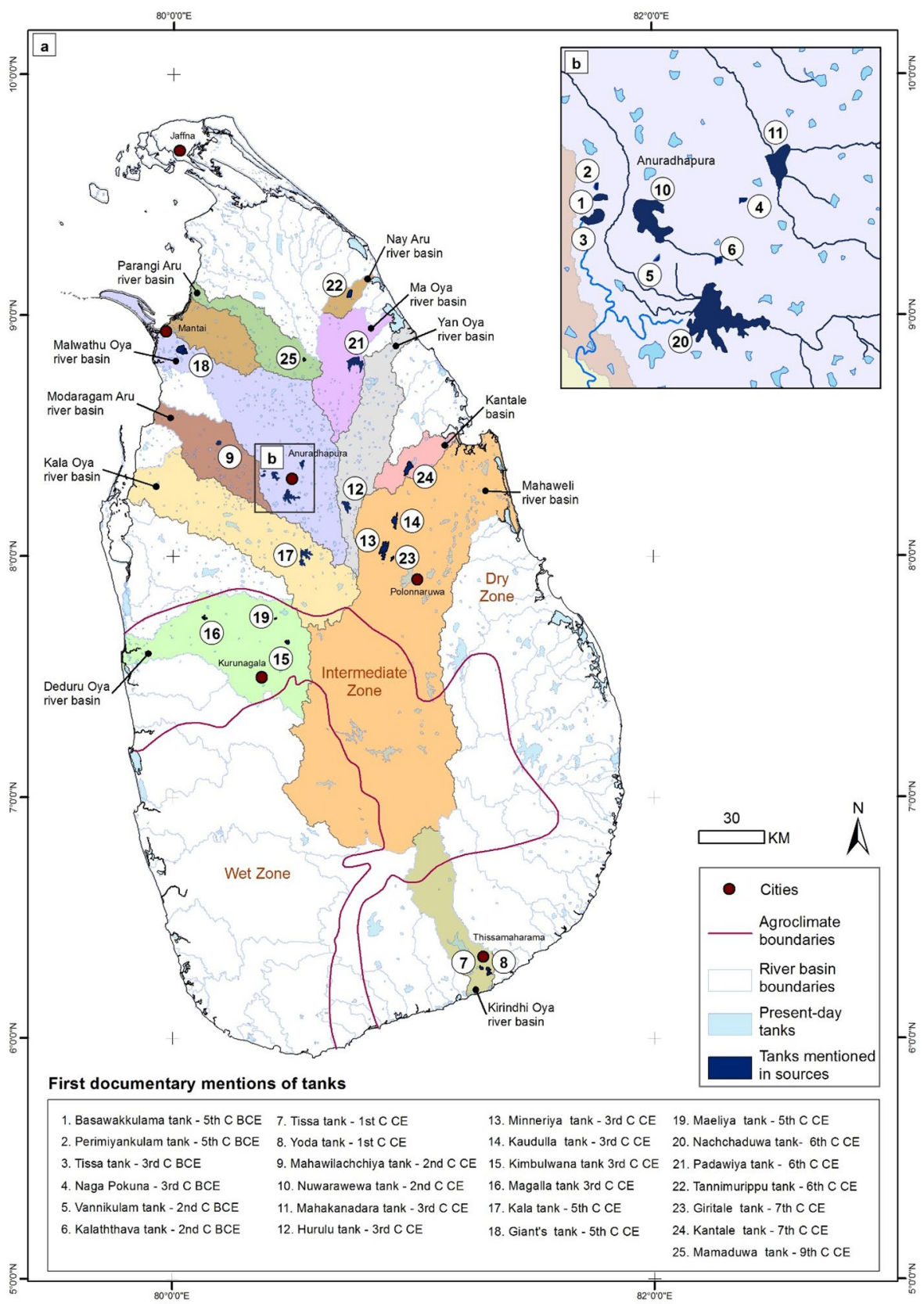

Fig. 4 Major irrigation works in Sri Lanka during the Anuradhapura Kingdom. Data source location of present-day tanks are based on survey department 1:250,000 maps, climatic zones are based on National Atlas of Sri Lanka (Somasekaram et al. 1988) 


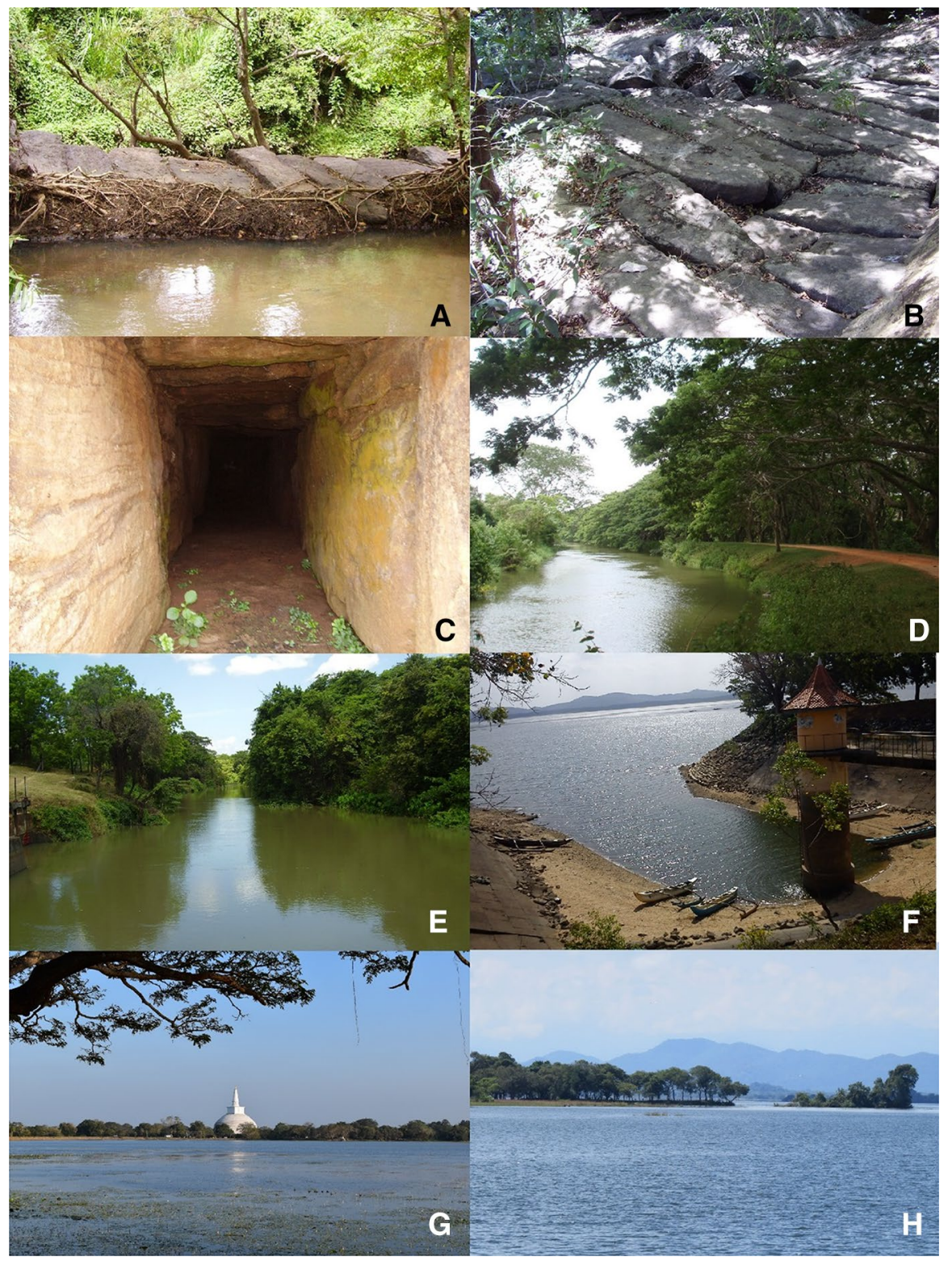

Fig. 5 Major irrigation elements in Ancient Rajarata Kingdom a Stone anicut-Hadaoya, b Stone anicutHattota, c Stone sluice-Maduruoya, d Yoda Ela canal, e Elahara canal, f Minneriya tank, g Basawakkulama tank, h Parakrama Samudra tank

in identifying as the present-day Perimiyankulam tank (Mahavamsa X/101) (Fig. 4, number 2). King Devanampiya Tissa (reign: 307-267 BCE) is credited with the construction of Tissavapi (present-day Tissa tank according to Geiger (1908), and Ranawella (2004)) located this tank south-east of the ancient center of Anuradhapura (Fig. 4, number 3). In the second century CE, during the reign of King Gajabahu (reign: 113-135 CE) a slab 
inscription erected in the Tuparama monastery in Anuradhapura mentioned Nagaravapi or the present-day Nuwarawewa (IC, II. Part 1. No. 60) (Fig. 4, number 10).

Vannikulam and Kalaththava (Fig. 4, numbers 5 and 6) are two medium-sized tanks constructed approximately $15-10 \mathrm{~km}$ southeast of the ancient city center of Anuradhapura during the reign of King Duttagamini (reign: 161-137 BC) (Mahavamsa XXV/66, XXVIII/39). Further, the Mahavamsa reports that King Duttagamini camped south of Kasapabbatha mountain (identified by Geiger (1908) as Kahalagama village c. $30 \mathrm{~km}$ south-east of Anuradhapura), where he built a tank and held a water festival during warfare (Mahavamsa XXV/50). King Vasabha (reign: 66-110 CE) created eleven large tanks including Chayanthi, which corresponds to the present-day Mahavilachchiya tank (Diksith 1986; Dipavamsa XXII.7-8; Mahavamsa XXV/94-96) (Fig. 4, number 9). King Mahasen (reign: 276-303 CE) was responsible for the construction of 16 tanks including two large tanks added to the hinterland of Anuradhapura, namely the ancient tank Khanu corresponding to the recent Mahakandarawa tank in Mihintale (Gunawardana 1971) and Chhallura identified as Huruluwewa in the river basin of the Yan Oya (Fig. 4, numbers 11 and 12) (Mahavamsa XXXVII/47). The large reservoir Kala wewa, located c. $50 \mathrm{~km}$ south of Anuradhapura on the watershed of the Kala Oya River, was constructed during the reign of King Dathusena (reign: 459-477 CE) (Culavamsa XXXVIII/45) (Fig. 4, number 17). It is reported that King Moggallana II (reign: 531-551 CE) dammed the Malwathu Oya and diverted water through a canal to build the Pattapasanavapi, corresponding to the recent Nachchaduwa tank in the hinterland of Anuradhapura (Diksith 1986; Culavamsa XLI/61) (Fig. 4, number 20). Furthermore, King Moggallana II was credited with the construction of the Dhanavapi tank, which corresponds to the present-day Padaviya tank in the Ma Oya river basin (Culavamsa XLI/61) (Fig. 4, number 21).

From the first century CE onwards, the ancient chronicles mention major tanks as being situated in parts of the country not in the immediate environs of the ancient capital Anuradhapura. During the reign of King Ilanaga (reign: 35-44 CE) two tanks situated in the Rohana Kingdom are mentioned in the chronicles (Mahavamsa XXXV/32, Dipavamsa 13/11). The Mahavamsa and Dipavamsa report on restoration works at Thissavapi and Duravapi (Mahavamsa XXXV/32, Dipavamsa XI/11); these tanks were identified by Parker (1909) as Tissa wewa and Yoda wewa in Thissamaharama (Fig. 5, numbers 7 and 8). In the third century CE, during the reign of King Mahasena (reign: 276-303 CE), two major tanks, namely Manihira (Minneriya tank, identified by Geiger (1908)) and Tissavaddhamanaka (Kavudulla tank, identified by Codrington (1995)) were constructed in the environs of Polonnaruva (Mahavamsa XXXVII/47-50) (Fig. 4, numbers 13 and 14; Fig. 5f). The construction of the large reservoir Manamathu, identified as Giant's tank by Gunawardana (1971), c. $18 \mathrm{~km}$ west of the ancient harbor of Mantai, indicates an expansion of water management systems to the north-west during the reign of King Dathusena (reign: 459-477 CE) (Culavamsa XXXVIII/45) (Fig. 4, number 18). King Aggabodhi II (reign: 608-618 CE) promoted extensive irrigation projects in the eastern part of the country (Culavamsa XLII/67). This included the construction of Gangatata (according to Gunawardana (1971) corresponding to the large reservoir Kantale in the Trincomalee district) and Giritata (according to Gunawardana (1971) corresponding to Giritale in the Polonnaruva district) (Fig. 4, numbers 24 and 23). Later, in the ninth century CE, an inscription dated to the reign of King Sena II (reign: 853-887 CE) mentions a medium-sized tank called Mahidavava located c. $65 \mathrm{~km}$ north of Anuradhapura (identified as the Mamaduwa tank by Ranawella (2001)) (IC.V, part 1/14.9) (Fig. 4, number 25).

From the eighth century CE onwards sources report the restoration of dilapidated tanks. For instance the Culavamsa referred to the restoration of a tank named Godigamika by 
King Manavamma (reign: 684-719 CE), the dam of which burst several years earlier (Culavamsa XL/48/9). King Udaya II (reign: 935-938 CE) is credited with the restoration of numerous irrigation works during the tenth century CE (Culavamsa LI/121). According to the Jethavamarama slab inscription, dilapidated tanks and ponds were also repaired during the reign of King Mahinda IV (reign: 982-1018 CE): “( ...) [he repaired] the dilapidated [tanks and ponds] and by means of the water thus supplied he [put an end to] scarcity of food in the Island of Ceylon" (EZ.1, pp 230).

\section{Canals}

Early Brahmin inscriptions from the second century BCE to first century CE mention numerous canals in the Dry Zone (Table 2). However, precise geocoding was not successful for the canals mentioned in ancient inscriptions as these references were often mentioned in relation to grants or incomes from irrigation works. The Molahitiyawegala rock inscription of King Bathikabaya (reign: 20 BCE-9 CE) reports the following:

Success! King Abhaya eldest son of King Kutakanna and grandson of the great King Tissa, the Friend of the Gods dedicated, by means of the golden vase the channel at Galatataka to the Community of bhikkhus in the Payelipavata monastery (IC, II, Part $1 / 18 \mathrm{~A})$

The Mahavamsa reports on subterranean canals (ummagga najalam) supplying water to the bathing tanks in Anuradhapura, constructed by King Vasabha (reign: 66-110 CE) (Mahavamsa XXXV/98). From the second century CE, sources provide evidence of extensive canals constructed by damming up rivers and other waterways (Table 3 ).

The last identified canal mentioned in the sources during the period of the Anuradhapura Kingdom originates from the Vessagiriya slab inscription erected during the reign of Mahinda IV (955-972 CE). Here a canal named Kolomhoya is mentioned. The inscription most probably refers to the present-day canal Halpanu (Ranawella 2004), which runs east of the ancient city following the eastern border of the floodplain of the River Malwathu Oya.

\section{Grants of irrigation}

From the second century BCE onwards numerous grants of irrigation are recorded in ancient written sources. The majority of records report grants of irrigation by the kings, elites and local communities to Buddhist monasteries. For the majority of the records, religious reasons are clearly the main motivation for the grant. Secular grants are mentioned in only a few sources. For instance, King Datusena (reign: 459-477 CE) granted half of the share of the Kalavapi or the Kala wewa (Kalavapimhi bhagaddham) to his brother Kumarasena (Culavamsa XXXVIII/53). According to the sources, grants are identified in different categories as follows: Grants of tanks

- Grants of waterholes

- Grants of cisterns

- Grants of parts of tanks

- Re-grants of tanks

- Grants of fields by the tanks

- Grants of pasturelands by the tanks 


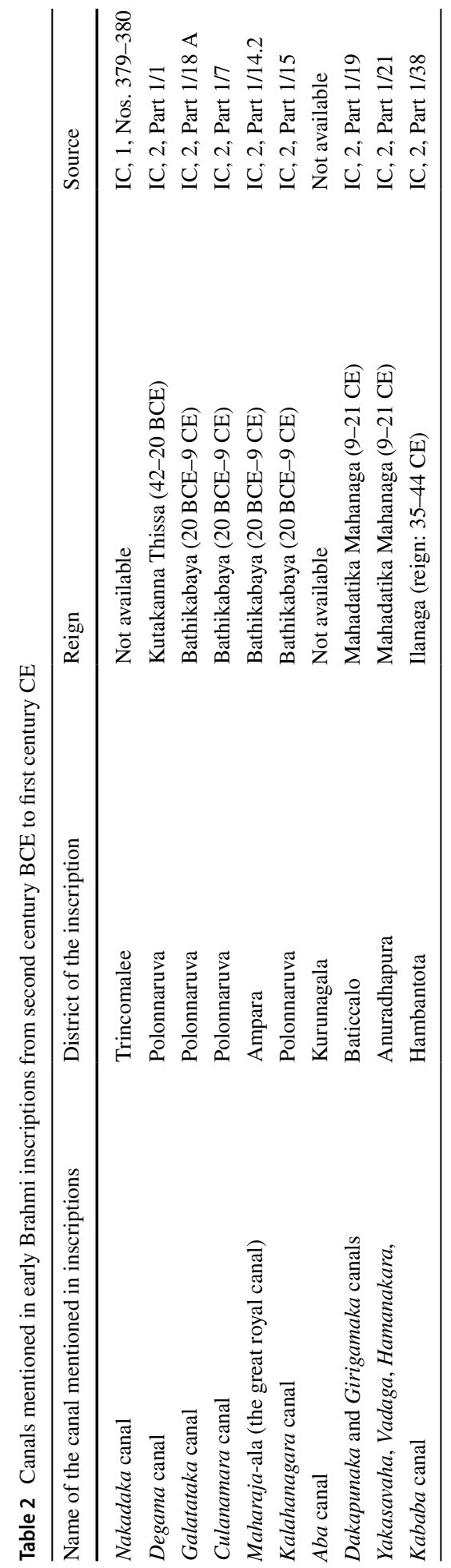




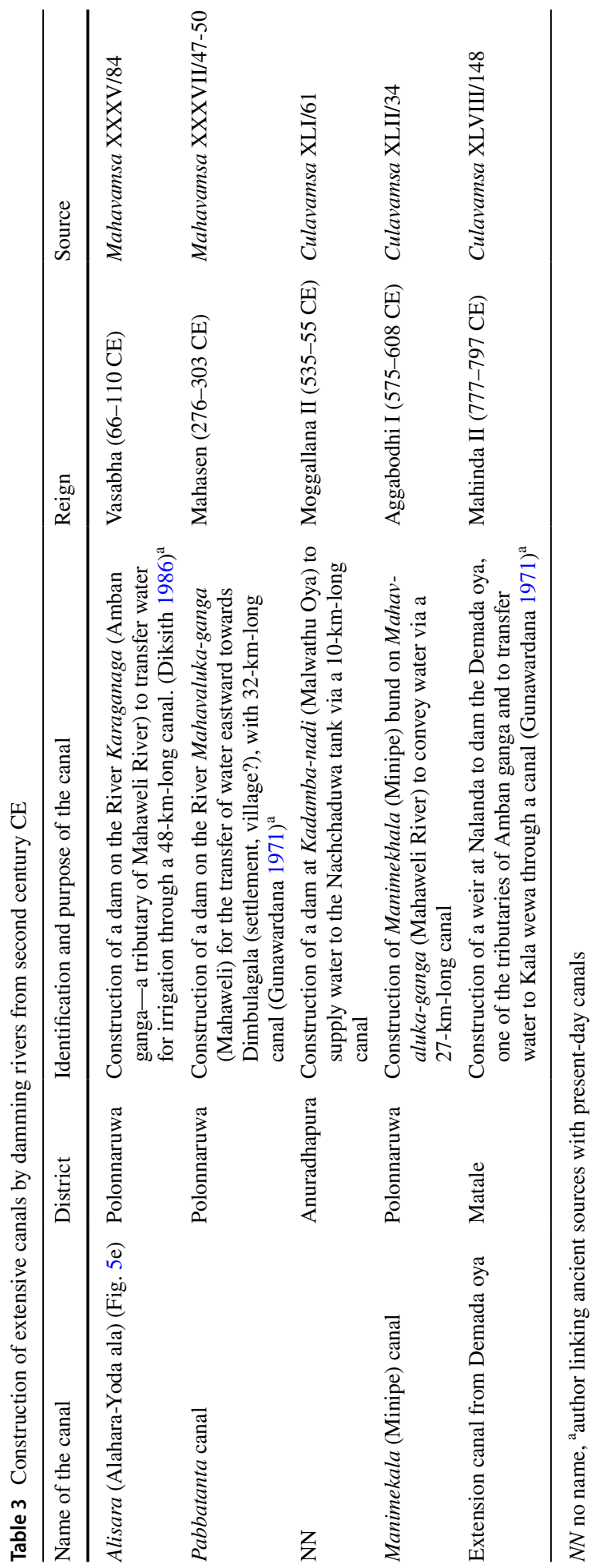


- Grants of canals

- Grants of water shares

- Grants of water revenues

\section{Irrigation taxes, shares and income}

The earliest reference to irrigation taxes in the written sources dates to the first century BCE (IC 2, part 1/11). Taxes were mainly charged for the water of the tanks and the canals. Sources mention revenues in different ways, such as revenues for tanks and canals (IC, II, Part 1/14.1), proprietor's share (IC, II, Part 1/11), share of water (IC, II, Part 1/14.2), share of fish caught in the tanks/canals (IC, II, Part 1/41) and income from the pasturelands by the tanks (IC, I, No. 1150). Further, there are a few indications about the organization of taxation like revenue districts. A Tammannakanda rock-inscription dating to the second century BCE refers to three tanks situated in the revenue district called Utarapara, dated to second C CE (IC, II, Part 1, 72). Akurugoda slab-inscriptions mention a grant made by a revenue officer to the monks (IC, I, No. 703).

\section{Professions, laws and official announcements}

Early Brahmi inscriptions from the second century BCE to the first century CE mention different professions related to irrigation agriculture such as flow operators (Naguli), officers in charge of canals, proprietors of ferries (Parumaka Thota Bojhaka), proprietors of the pasturelands and proprietors of tanks (Parumaka vapihamika) (IC, I. No. 260, 869, 791, $846,860,1129,1130,1132,1122,1149)$. As only the names are given in the texts detailed information on the rights and obligations of these groups of persons are lacking. After the ninth century CE agriculture officers are frequently mentioned in inscriptions (IC, V. part 1. No. 94.4, 97.1, 112.22, IC, V. part 2. No. 7.7, 8.8, 41.4, IC, V. part 3. No. 4, 11, 27, 70, $78,89,120)$.

A few inscriptions from the tenth century CE, such as the Dorabavila inscription, mention 12 great reservoirs related to official orders (IC, V. part 1. No. 100.10); however, information on the names of the reservoirs is omitted. The Basawakkulama pillar inscription dating to tenth century $\mathrm{CE}$ is located on the margin of the Basawakkulama tank in Anuradhapura and was established to prevent illegal fishing in the tank (IC, V. part 1, No. 10.5).

\section{Discussion}

\section{Source criticism}

Analysis of historical text sources requires a sound examination of the reliability of the derived information (Wenham 1979). Source criticism is a standard method in historical disciplines, targeting the assessment of the circumstances in which a historical source was written. The motivation and background of the author of a source is of particular interest (Viviano 1999).

In Early Historic Sri Lanka classical texts and chronicles were written by scholar monks with a specific and limited agenda, for instance to support the establishment of particular faiths, lineages, and ritual centers throughout the island (Seneviratne 2008). Furthermore, chronicle texts are in places infused by narratives based on historical facts and myths 
originating from North India as well as stories of inventions and confrontations linked to South India (Seneviratne 2008). The Mahavamsa, the main written source analyzed in this paper, is characterized by its translator Wilhelm Geiger rather as a poem than a pure chronicle, which results in the occurrence of embellishments and exaggerations (Geiger 1930). Nonetheless, Geiger (1930) was convinced that despite their religious bias the authors did not intentionally record falsehoods. It is, however, of utmost importance to evaluate all the analyzed text to avoid consideration of the information being biased by the two above-mentioned aspects. The value of information given in a source depends on its chronological proximity to the documented events (Ray 1960). This general statement does not hold true for the early records derived from the Mahavamsa, as chroniclers had access to commentaries given in the Pali Canon named Atthakatha Mahavamsa, which was written before the Mahavamsa. In later centuries the Atthakatha Mahavamsa was no longer available to chroniclers.

The analyzed inscriptions predominantly address common acts such as grants of cavedwellings, monasteries, land, tanks, villages and revenues from the tanks and lands (Dias 2001). In contrast to the classical texts, inscriptions widely document, or comment on, contemporary aspects and are not predominantly influenced by religious perspectives or tales (Paranavithana 1970).

Several scholars have assessed the suitability of the classical texts and inscriptions as a source for the derivation of historical events. For instance, Adithiya (1984) analyzed aspects of ancient architecture and town planning from the Mahavamsa, and Liyanarachchi (2009) based his research on accounting in ancient Sri Lanka on lithic inscriptions. In summary, it can be stated that the analyzed sources represent a valuable archive for the derivation of information on the chronological and spatial development of the water harvesting and management system in Sri Lanka.

\section{The spatial and temporal distribution of records}

The identification of territories in archaeological and historical research is challenging (Nakoinz 2012). This holds true for a clear delineation of the hinterlands of the ancient capitals of Anuradhapura and Polonnaruwa. As a work-around, present-day administrative units were used as the basis for the analysis of the spatial distribution of the records. A geostatistical delimitation as introduced by Nakoinz (2012) does not appear feasible due to the limited number of known settlement sites.

De Silva Wicremasinghe (1912) calls for a certain degree of caution in the evaluation of spatial information derived from lithic inscriptions. The spatial assignments made in this study are based on place names and, especially for inscriptions, the location of the records themselves. As the resulting distribution of records shows a clear spatial pattern with the majority of records located in the district of Anuradhapura (North Central Province), followed by the district of Kurunagala (North Western Province), the spatial assignment appears to be robust. This is confirmed by the present-day spatial distribution of tanks in the Dry Zone of Sri Lanka (Table 4). At present the North Western Province, comprising the districts of Kurunagala and Puttalam, shows the highest density of small tanks with 0.8 tanks $\mathrm{km}^{-2}$, followed by the North Central Province-corresponding to the districts of Anuradhapura and Polonnaruwa, with 0.4 tanks $\mathrm{km}^{-2}$. The lower density of tanks in the North Central Province in relation to the highest frequency of records from ancient sources can be explained by the general political importance of the area around the ancient capital Anuradhapura and the considerable impact of major tanks in its hinterland. 


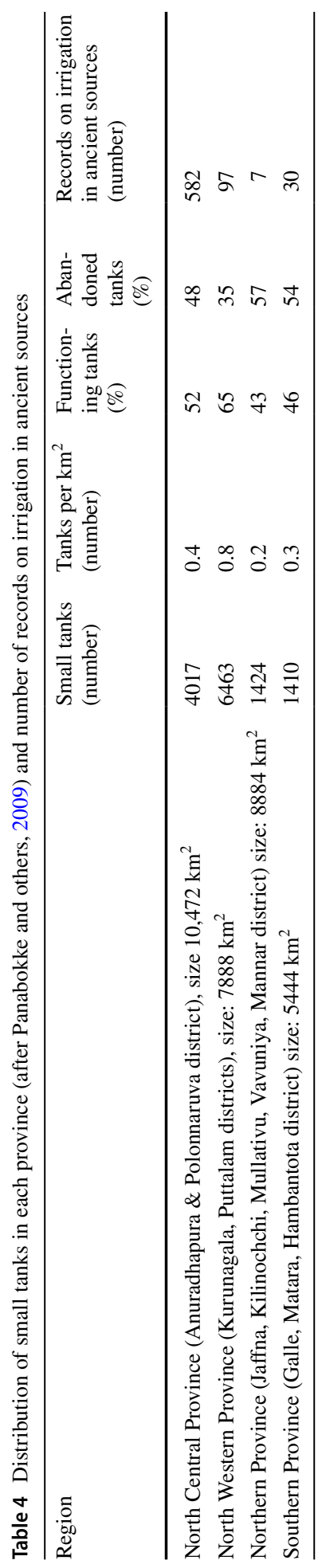


When discussing the spatial distribution of records the state of the research also has to be considered as a biasing factor. From the Colonial Period onwards, the ancient urban and ritual centers such as Anuradhapura, Polonnaruwa and Thissamaharama with their monumental architectural ruins and massive irrigation schemes comprised the research focus of historical and archaeological studies (Seneviratne 2008). The peripheral regions of Sri Lanka made up a research desideratum in the past and have only recently been discovered for the purposes of systematic archaeological investigations, for instance Kantharodai on the Jaffna peninsula (Bohingamuwa 2017). Furthermore, the political and religious power of the ancient urban and ritual centers led to a considerably higher number of written sources, compared to more peripheral regions. Thus differences in the state of research and in the general heterogeneous distribution of sources have to be considered when interpreting the data presented here, especially in terms of explaining the large number of sources and records from early urban centers in Sri Lanka. However, the studied inscriptions were located in a pan-island context covering the majority of districts in the Dry Zone of Sri Lanka.

In the Northern Province the civil war (1983-2009) has to be regarded as another aspect influencing the spatial distribution of records available (Thiranagama 2011). Due to the civil war archaeological and epigraphic research in the northern part of the country is rare. Furthermore, the north-western coastal plains consist of limestone bedrock, which due to its exposition to weathering is less suitable for the preservation of inscriptions than the metamorphic rocks characterizing the Dry Zone of Sri Lanka (Somasekaram 1988). The interplay of these factors probably resulted in a comparably low number of ancient written sources from the Northern Province. This is remarkable, because with the ancient port of Mantai an ancient trade center is situated in this region. Further, the area north-west of Anuradhapura up to the coast is characterized by a reasonable number of tanks and mentioned in the sources as the "rice bowl" of the country (Prickett-Fernando 1990).

The temporal distribution of records depends on numerous factors. According to the analyzed sources, the first references to Dry Zone water harvesting and the water management systems are found in a few records from the fifth and fourth centuries BCE with a gradual increase in references after the third century BCE, reaching a maximum in the second century $\mathrm{CE}$ (Fig. 3). It is argued here that this phenomenon is correlated with the introduction of Buddhism in the third century BCE followed by a serious of donations to Buddhist entities often linked with lithic inscriptions (Paranavithana 1970). However, a sudden decrease in records can be seen after the fourth century CE. In addition, the temporal distribution of records is directly affected by the availability of published materials. Analyzed records of the categories "canals", "grants of irrigation works", "taxes, shares and income" and "laws and official announcements" show their scarcity between the fourth century and seventh century CE. Two important publications, which are intended to catalogue the inscriptions of this period are in preparation for publication by the Department of Archaeology (IC volumes 3 and 4) (friendly oral communication by Mr. Namal Kodithuwakku, Director-Epigraphy and Numismatics, Department of Archaeology Colombo, August 2017). The discontinuities in the published inventory of inscriptions between the fourth and seventh centuries CE permit only a coarser temporal resolution for this period.

\section{Development of the water harvesting and water management systems}

The dataset introduced here provides information on the development of the ancient water harvesting and water management systems of Sri Lanka that goes beyond the presentation of a simple list of tank constructions. 


\section{Construction of large-scale tanks (fifth century BCE to second century CE)}

The earliest records on tanks, ponds and water holes relate to the ancient capital of Anuradhapura and its hinterland and began in the fifth century BCE, resulting in the hypothesis that the foundation of the ancient water harvesting and water management systems originates from this region (Fig. 3). The first tank Abhayavapi was mentioned between 437 and 367 BCE (Mahavamsa X/84-88). The large-scale tanks located west of the Citadel of Anuradhapura-the Basawakulama tank, Perimiyankulam tank and Tissa tank-were constructed by the early first century BCE. Between the fifth century BCE and the first century $\mathrm{CE}$ the total number of records relating to water harvesting and water management systems is relatively low (a total of 83). Records on canals and different professions associated with the processing and maintenance of irrigation works, like the proprietors of tanks and canals, allow the conclusion to be drawn that the water harvesting and water management system had already been transformed from decentralized, village-based systems to a centralized system managed, by the state bureaucracy, by the second century BCE. The simultaneous appearance of grants for irrigation works confirms this conclusion. Decentralized irrigation management is a community driven natural resource management system where communities manage natural resources upon which they depend for their livelihoods (Mosse 1999) This period between fifth century BCE and first century BCE also corresponds to the transformation of the settlement of Anuradhapura from a rural village to the capital of the Anuradhapura Kingdom (Coningham 2013; Deraniyagala 2007), including the construction of the main Buddhist monasteries which form a semi-circle around the ancient Citadel area (Bandaranayake 1974; Silva 2000; Wagalawatta et al. 2015). In the first century CE the Citadel of Anuradhapura comprised an area of 100 ha (Deraniyagala 1992) and was among the largest ten cities of the Indian sub-continent (Allchin and Allchin 1999).

In the second century CE records of all categories peak except the category "laws and official announcements". This peak of records points to parallels in the development of the water management systems and the urban monastic development of Anuradhapura, as the Buddhist monasteries functioned as administrative bodies but also represent centers of knowledge (e.g. scripture). The example of "grants for irrigation works" illustrates this clearly: in total 119 records of grants for irrigation works were recorded, of which $67.2 \%$ originate from the hinterland of Anuradhapura. As the majority of grants for irrigation works had a religious background, the peak of this category clearly documents how the monastic culture led to an increase in records related to the ancient water harvesting and water management systems.

The period between the first century BCE and the fifth century CE was characterized by political stability, as just one non-destructive invasion from southern India is recorded in the chronicles (Table 5). Political stability is generally regarded as a factor sustaining the development of cultures and consequently the development of land management systems (Bozeman 2017; Halpern 2015).

In summary, the peak of records in the second century CE clearly points to the increasing demand to record different aspects of the water harvesting and water management systems and the development of corresponding administrative structures to manage these systems. Consequently, we have to be careful about exclusively correlating this peak to the possible number of existing tanks. Other authors also date the initial development stage of the ancient water harvesting and water management systems to this period (Gilliland et al. 2013). 


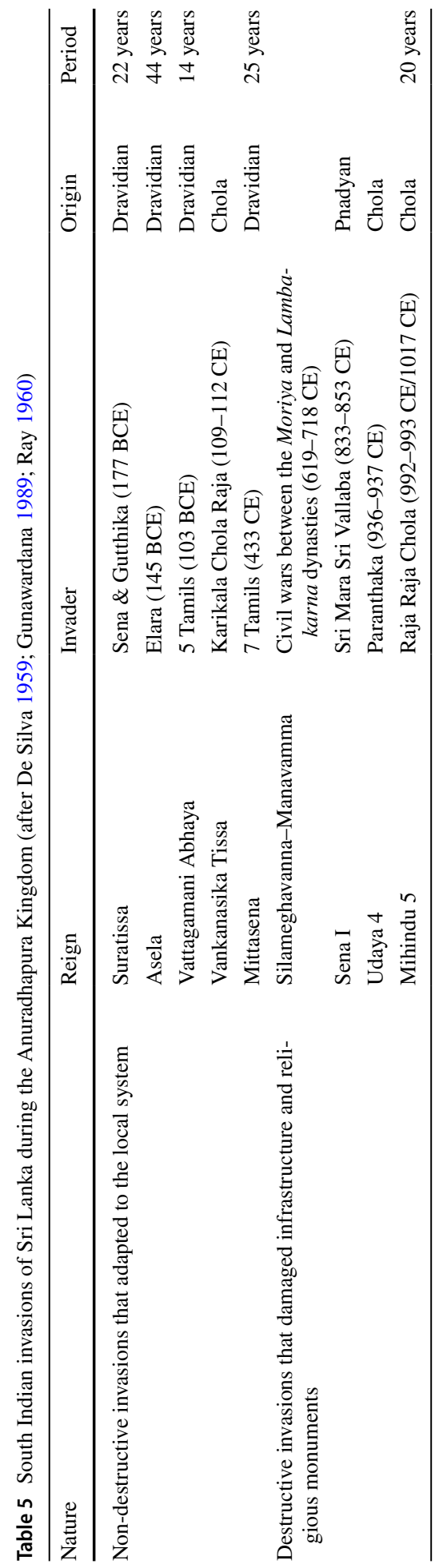


According to the literary and archaeological sources, the southernmost Rohana Kingdom with its citadel Akurugoda started flourishing in parallel with the Anuradhapura Kingdom, from fifth/fourth century BCE onwards (Ray 1960; Weisshaar 2007). However, according to the analyzed sources, water harvesting and water management was initiated in Rohana Kingdom in the second century BCE, while the first identifiable larger tanks were mentioned in the first century CE (Parker 1909) (Fig. 4). Compared to the Anuradhapura hinterland few records witness to water harvesting and water management activities in this southern territory. In general, it is assumed that the development of large-scale irrigation in Rohana Kingdom more or less parallels the major tank constructions in the Anuradhapura hinterland until the early first century CE.

\section{Spread of the water harvesting and water management systems}

The analysis of the ancient written sources demonstrates that the spreading of large-scale water harvesting and water management projects from the hinterland of Anuradhapura to other regions in the Dry Zone took place from the third century CE onwards (Table 3, Fig. 4). The implementation of large-scale water harvesting and water management works occurred in the immediate hinterland of Anuradhapura (catchment of the Malwathu Oya River) and the neighboring Kala River catchment (located adjacent to and south of the catchment of the Malwathu Oya River and west of the catchment area of the Mahaweli Ganga River) (Gunawardana 1971; Fig. 4). The water management system in the Kala River catchment is based on the functional affiliation and interconnectedness of water routing between the catchments of the Mahaweli River and the Malwathu Oya River via the catchment of the Kala River (Gunawardana 1971). By at least the eighth century CE water was routed via a dammed-up tributary of the Amban Ganga River, a tributary of the Mahaweli River, and via a canal towards the Kala wewa (Culavamsa XLVIII/148) and further to the large-scale tanks Tissa Wewa, Nuwarawewa and Nachchaduwa near Anuradhapura, thus increasing the amount of irrigation water in the hinterland of Anuradhapura. Under the reign of the Kings Mahasen (reign: 276-303 CE), Dathusena (reign: 459-477 CE) and Aggabodhi II (reign: 608-618 CE) large-scale tanks were constructed in the hinterland of Polonnaruwa and in the catchment of the Kala river, which is located south of the Malwathu Oya catchment. Gunawardana (1971) emphasizes these two areas as "nuclear areas" or "irrigation complexes". The large-scale tanks in the hinterland of Polonnaruwa include Minneriya and Kaudulla (both constructed in the third century CE), and Giritale and Kantale (constructed in the seventh century CE).

Unlike the catchment of the Malwathu Oya River, the headwater area of the Mahaweli River is located in the humid highlands of the Central Province and is regarded as the only perennial river of Dry Zone Sri Lanka (Gunawardana 1971). From c. $300 \mathrm{CE}$ onwards the tanks in the direct hinterland of Anuradhapura appeared insufficient to supply the growing population (Coningham et al. 2007; Deraniyagala 2007) with the required amount of irrigation water for rice cropping, so that rulers were forced to develop a new strategy by the end of the second century CE. This challenge was preceded by a number of droughts leading to water and food shortages (Mahavamsa XXXVI 20, 75-79). Already in the fourth century CE during the reign of King Sirimegahavanna (reign: 303-331 CE) an inscription in Thonigala, located c. $80 \mathrm{~km}$ south-west of Anuradhapura, reports about three harvests per year (EZ III, 99 177, 178), pointing to an improvement in the supply conditions of local communities. Indirectly, travel reports by the Buddhist Chinese monk Fa-hsien, who visited Anuradhapura around the fourth 
or fifth century CE, also provide information on the remarkable capacity of Dry Zone agriculture to derive a surplus of agricultural products, as he reports about 50,000 to 60,000 monks living in the area and receiving food from a common stock (Giles 1923). In addition, the king of Anuradhapura provided a common stock of food for nearly 6000 monks daily within the city (Giles 1923).

The analysis of the ancient written sources clearly shows that the strategy to stabilize food production was based on the expansion of the water harvesting systems from the hinterland of Anuradhapura to the hinterland of Polonnaruwa. Beyond, water was routed between catchments via canals. The construction and functioning of canals crossing divides is only poorly documented in the analyzed sources (Table 5; Culavamsa XLVIII/148), but together with the constructional remains of these canals, the transcatchment boundary routing of water and its origin in the Middle Historic period is unequivocally documented (Brohier 1997; Parker 1909). Contrastingly, numerous canal constructions indicate an increase in the utilization of river water from the first century CE onwards as a complementary water source originating from local water harvesting (Table 4). Today, water from the Mahaweli River is routed through a complex and highly regulated system to the catchments of the Rivers Kala Oya, Aruvi Aru/Malwathu Oya, Yan Oya, Maduru Oya and Kantale (Mahaweli Diversion Scheme 2018).

The successive expansion of the water harvesting and water management systems is documented in the sources from the third century CE to the eighth century CE and, thus, covers the period for which the compilation of inscriptions of Ceylon, volumes 3 and 4, is still in preparation for publication (friendly oral communication by Namal Kodithuwakku, Director-Epigraphy and Numismatics, Department of Archaeology Colombo, August 2017). This has to be considered as exacerbating the data gap, causing the poor chronological resolution of the different measures. Nevertheless, Gilliland et al. (2013), also applying sedimentological analysis and OSL dating, identified indicators suggesting a reorganization of the water harvesting systems in the hinterland of Anuradhapura from $700 \mathrm{CE}$ onwards. These findings correlate with the addition of new tanks such as the Nachchaduwa tank in the sixth century CE (Culavamsa XL1/61).

Besides the two major irrigation complexes in Anuradhapura and Polonnaruwa discussed above, three minor water harvesting and management complexes were identified (Fig. 4). These are located in (i) the Kirindi Oya catchment, dated to the second century BCE to first century CE, (ii) the Nay Aru and Ma Oya catchment, dated to the sixth century CE, (iii) the Daduru Oya catchment, dated to the third century CE to fifth century CE (Fig. 4). These minor irrigation complexes clearly indicate the extension of water harvesting and water management systems throughout the entire Dry Zone. However, systematic investigations are required to correlate these minor irrigation complexes with the spread of settlements throughout the Dry Zone. In addition, the Giant's tank dating to the fifth century $\mathrm{CE}$, which irrigates the hinterland of Anuradhapura's ancient harbor area Manthai, needs to be mentioned as a water harvesting and water management measure established beyond the ancient centers (Fig. 4).

The village tank cascade systems as decentralized water management systems are rarely mentioned in the ancient sources analyzed here. Nonetheless, Gunawardana (1971) acknowledged their important role for the local communities as storage reservoirs for irrigation water and as a genuine element of sustainable agriculture as practiced by the rural population. The local communities even continued utilizing these village tank systems after the abandonment of Anuradhapura in the eleventh century CE (Gilliland et al. 2013; Gunawardana 1971). 


\section{Decline of the water harvesting system in Anuradhapura Kingdom}

The period between the eighth century $\mathrm{CE}$ and eleventh century $\mathrm{CE}$ was characterized by numerous invasions by groups from South India and can be regarded as a period of political instability (Codrington 1995; De Silva 1959). The destruction of infrastructure, in particular of tanks, by the invaders is reflected in the sources through mentions of restorations of dilapidated tanks (Culavamsa XL/48/9, LI/121, EZ.1, pp 230). Parallel to this, during the ninth and tenth centuries $\mathrm{CE}$, numerous records deal with irrigation laws and official announcements, indicating a stronger development of bureaucratic and centralized water management structures with various officials e.g. agriculture officers and regulations for large-scale partly interconnected tanks. Before this implementation phase when bureaucratic structures were developed, there is a period for which only a few records are available (fourth-seventh centuries CE) so it is not possible to determine whether this increase in bureaucracy had perhaps started centuries earlier. A systematic compilation of inscriptions for this period is being prepared for publication; in consequence this evidence is tentatively interpreted as terminus ante quem.

It is assumed that the development of a centralized bureaucratic administration was a measure intended to counter destruction by the invaders and continue the management after destruction. In addition, it is most likely that the invasions hindered the construction of further large tanks, finally leading to the abandonment of Anuradhapura as the capital of the kingdom of the same name in the eleventh century.

\section{Conclusions}

This investigation aims to fill the research gap by compiling a systematic analysis of ancient sources on the water harvesting and water management systems of Sri Lanka. The current analysis documents the potential of the analyzed source genres for the derivation of information on different aspects related to the spatial, temporal and administrative development of ancient water harvesting and water management systems in Sri Lanka.

The inscriptions, classical texts and chronicles of Sri Lankan historiography were written with a specific agenda, however, they provide trustworthy information on the development of the ancient water harvesting system. It needs to be considered that the density of sources for centers of political and religious power like Anuradhapura and Polonnaruwa is higher than for more peripheral areas of the Dry Zone. Nonetheless, the hinterland of the ancient capital Anuradhapura was confirmed as the nucleus for the development of this system, and a successive spreading across the Dry Zone of Sri Lanka can be traced. The first mentions of large-scale tanks date to the fifth and fourth centuries BCE and such references peak in the second century $\mathrm{CE}$, paralleling the (peri)urban and religious development of Anuradhapura and its hinterland. During the third century CE, Anuradhapura reached saturation point in the construction of major tanks in the catchment of the River Malwathu Oya. During the following centuries, rulers put a strong emphasis on the spreading of such systems to the environs of Polonnaruwa, located in the catchment of the Mahaweli River. As a result, in the eighth century CE, two major complexes of water management systems were developed, supplying Anuradhapura and Polonnaruwa with water. These two complexes were successively connected by canals, enabling the trans-catchment routing of water between the more humid catchment of the Mahaweli River via the catchment of the 
Kala River to the catchment of the Malwathu Oya River. In the ninth and tenth centuries, the water harvesting and water management infrastructure was partly destroyed by invaders from South India. Furthermore, these two centuries were characterized by a peak of records focusing on administrative aspects, indicating a strengthening and systematization of bureaucratic structures.

The analyzed sources reveal little information on small-scale community-driven village tank systems, but it is largely assumed that the ancient rural water harvesting and water management systems in Sri Lanka developed as local community-based systems and gradually evolved to an integrated watershed management system under the responsibility of the kings (Gunawardana 1971). This important perspective on the development of the system partly contradicts Karl Wittfogel's hydraulic hypothesis that societies in Asia are mainly based on large-scale state-controlled irrigation projects constructed using forced labor under a centralized bureaucratic administration (Wittfogel 1959).

Acknowledgements We sincerely thank the Volkswagen Foundation for funding this study as part of the joint research project "Tank cascade systems as ancient measures of integrated Watershed Management in the Dry Zone of Sri Lanka" between the Freie Universität Berlin and the University of Peradeniya (ProjectID: 88578). Further, we are thankful to Mr. Kalpa Asanga, Department of Archaeology, Sri Lanka for his assistance in acquiring some inscription volumes.

Open Access This article is distributed under the terms of the Creative Commons Attribution 4.0 International License (http://creativecommons.org/licenses/by/4.0/), which permits unrestricted use, distribution, and reproduction in any medium, provided you give appropriate credit to the original author(s) and the source, provide a link to the Creative Commons license, and indicate if changes were made.

\section{References}

Abeywardana N, Bebermeier W, Schütt B (2018) Ancient water management and governance in the dry zone of Sri Lanka until abandonment, and the influence of colonial politics during reclamation. Water 10:1746. https://doi.org/10.3390/w10121746

Abeywardana N, Schütt B, Wagalawatta T, Bebermeier W (2019) Indigenous agricultural systems in the dry zone of Sri Lanka: management transformation assessment and sustainability. Sustainability 11:910

Adithiya LA (1984) Architecture and town planning in the pre-Christian Era from the Mahavamsa. J R Asiat Soc Sri Lanka Branch 29:75-102

Allchin B, Allchin R (1999) The rise of civilization of India and Pakistan, South Asia edn. Foundation Books, New Delhi

Bandara CM (1985) Catchment ecosystems and village TankCascades in the dry zone of Sri Lanka a timetested system of land and water resource management. In: Lundqvist J, Lohm U, Falkenmark M (eds) Strategies for river basin management. Springer, Dordrecht, pp 99-113

Bandaranayake SD (1974) Sinhalese monastic architecture: the viháras of Anurádhapura. BRILL, Leiden

Bebermeier W, Meister J, Withanachchi CR, Middelhaufe I, Schütt B (2017) Tank cascade systems as a sustainable measure of watershed management in South Asia. Water 9:231

Bohingamuwa W (2017) Sri Lanka and the Indian Ocean contacts: internal networks and external connections. $\mathrm{PhD}$ thesis

Bozeman AB (2017) Politics and culture in international history: from the ancient near east to the opening of the modern age. Routledge, London

Brohier RL (1935) Ancient irrigation works in Ceylon, vol 3. Government Record Office, Colombo

Brohier RL (1979) Ancient irrigation works in Ceylon. Ministry of Mahaweli Development, Colombo

Brohier RL (1997) Ancient irrigation works in Ceylon. Asian Agri-Hist, India

Codrington HW (1995) Short History of Ceylon. Asian Educational Services, New Delhi

Codrington HW, Paranavitana S (1934) Epigraphia Zeylanica, vol IV. Oxford University Press, Oxford

Coningham R (2013) Anuradhapura: the British-Sri Lankan excavations at Anaradhapura Salgaha Watta. Archaeopress, Oxford 
Coningham R, Gunawardhana P, Manuel M, Adikari G, Katugampola M, Young R, Schmidt A, Krishnan K, Simpson I, McDonnell G, Batt C (2007) The state of theocracy: defining an early medieval hinterland in Sri Lanka. Antiquity 81:699-719. https://doi.org/10.1017/S0003598X00095673

Dahdouh-Guebas F, Hettiarachchi S, Seen DL, Batelaan O, Sooriyarachchi S, Jayatissa LP, Koedam N (2005) Transitions in ancient inland freshwater resource management in Sri Lanka affect biota and human populations in and around coastal lagoons. Curr Biol 15:579-586

De Silva KM (1959) History of Ceylon. Ceylon University Press, Ceylon

de Silva Wicremasinghe DM (1912) Epigraphia Zeylanica, vol 1. Oxford University Press, London

Deraniyagala SU (1992) The prehistory of Sri Lanka: an ecological perspective. Department of Archaeological Survey, Government of Sri Lanka, Colombo

Deraniyagala SU (2007) The prehistory and protohistory of Sri Lanka. In: Deraniyagala SU, Silva R (eds) The art and archaeology of Sri Lanka. Central Cultural Fund, Colombo

Dias M (1991) Epigraphical notes. Department of Archaeology, Sri Lanka

Dias M (2001) The growth of Buddhist monastic institutions in Sri Lanka from Brahmi inscriptions. Colombo Dep. Archaeol. Surv, Colombo

Diksith DD (1986) Agriculture, irrigation and horticulture in ancient Sri Lanka. India Upasena Print, Delhi Geiger W (1908) Mahavamsa: great chronicle of Ceylon. H. Frowde ed. Oxford University Press, London

Geiger W (1930) The trustworthiness of the Mahavamsa. Indian Hist Q, vol VI

Giles HA (1923) The travels of Fa-hsien. Geographical Association, Cambridge

Gilliland K, Simpson IA, Adderley WP, Burbidge CI, Cresswell AJ, Sanderson DCW, Coningham RAE, Manuel M, Strickland K, Gunawardhana P, Adikari G (2013) The dry tank: development and disuse of water management infrastructure in the Anuradhapura hinterland, Sri Lanka. J Archaeol Sci 40:10121028. https://doi.org/10.1016/j.jas.2012.09.034

Gunawardana RALH (1971) Irrigation and Hydraulic Society in early Medieval Ceylon. Past Present 3-27

Gunawardana R (1989) Anuradhapura: ritual, power and resistance in a precolonial South Asian city. In: Miller D, Rowlands M, Tilley C (eds) Domination and Resistance. Unwin Hyman, London, pp $155-178$

Halpern M (2015) Politics of social change: in the Middle East and North Africa. Princeton University Press, Princeton

Institute IWM, Itakura J, Abernethy CL, Institute IIM (1993) Water management in a tank cascade irrigation system in Sri Lanka: first seasonal report of TARC-IIMI Joint Project 1991/1992 Maha Season. IWMI, Colombo

Jayasena HAH, Chandrajith R, Gangadhara KR (2011) Water management in ancient tank cascade systems (TCS) in Sri Lanka: evidence for systematic tank distribution. J Geol Soc Sri Lanka 14:29-34

Leach ER (1961) Pul Eliya: a village in Ceylon. Cambridge University Press, Cambridge

Liyanagamage A, Gunavardhana R (1965) Anuradhapura Yugaya, 2nd edn. Vidyalankāra University Press, Colombo

Liyanarachchi GA (2009) Accounting in ancient Sri Lanka: some evidence of the accounting and auditing practices of Buddhist monasteries during 815-1017 AD. Account. Hist. 14:101-120. https://doi. org/10.1177/1032373208098554

Madduma Bandara CM (1995) Tank cascade systems in Sri Lanka: some thoughts on their development implications (IWMI books, reports no. H016795). International Water Management Institute

Mahaweli Diversion Scheme (2018) Experience in integrated water resource integrated water resource management

Mosse D (1999) Colonial and contemporary ideologies of 'community management': the case of tank irrigation development in South India. Mod Asian Stud 33:303-338

Nakoinz O (2012) Models of Centrality. ETopoi J Anc Stud 3:217-223

Oldenberg H (1879) Dipavamsa. Asian Educational Services, New Delhi

Panabokke CR (2002) Small tanks in Sri Lanka: evolution, present status, and issues. IWMI, Colombo

Panabokke CR et al (1999) The small tank cascade systems of the Rajarata: their setting, distribution patterns, and hydrography. Mahaweli Authority of Sri Lanka, Colombo

Panabokke CR et al (2009) Small village tank systems of Sri Lanka: their evolution, setting, distribution, and essential functions. Hector Kobbekaduwa Agrarian Research and Training Institute, Colombo

Paranavitana S (1955) Epigraphia Zeylanica, vol. V, part I. Archaeological Survey Department of Sri Lanka, Colombo

Paranavitana S (1983) Inscriptions of Ceylon, volume 2: part 1. Department of Archaeology Sri Lanka, Colombo

Paranavitana S (2001) Inscriptions of Ceylon, volume 2: part 2. Archaeological Survey Department of Sri Lanka, Colombo 
Paranavitana S, Godakumbura C (1963) Epigraphia Zeylanica, vol V, part 2. Archaeological Department, Ceylon

Paranavitana S, Godakumbura C (1965) Epigraphia Zeylanica, vol V, part 3. Archaeological Department, Ceylon

Paranavitana S, Karunaratne S, Veluppillai A (1973) Epigraphia Zeylanica, vol VI. Archaeological Survey Department of Sri Lanka, Colombo

Paranavithana S (1970) Inscription of Ceylon: early Brahmi inscriptions, vol 1. Dep. Archaeol, Colombo

Parker H (1909) Ancient Ceylon. Asian Educational Services, New Delhi

Prickett-Fernando M (1990) Mantai-Mahatittha: the great port and entrepot in the Indian Ocean trade. Sri Lanka Silk Road Sea 115-121

Ranawella S (2001) Inscriptions of Ceylon, volume 5: part 1. Department of Archaeology Sri Lanka, Colombo

Ranawella S (2004) Inscriptions of Ceylon, volume 5: part 2. Department of Archaeology Sri Lanka, Colombo

Ranawella S (2005) Inscriptions of Ceylon, volume 5: part 3. Department of Archaeology Sri Lanka, Colombo

Ray HC (1960) History of Ceylon, vol 1. Ceylon University Press, Colombo

Saddhamangala K (1984) Epigraphia Zeylanica, vol VII. Archaeological Department, Ceylon

Sakthivadivel R, Fernando N, Panabokke CR, Wijayaratna CM (1996) Nature of small tank cascade systems and a framework for rehabilitation of tanks within them. International Irrigation Management Institute (IIMI)

Schütt B, Bebermeier W, Meister J, Withanachchi CR (2013) Characterisation of the Rota Wewa tank cascade system in the vicinity of Anuradhapura, Sri Lanka. ERDE J Geogr Soc Berl 144:51-68

Seneviratne S (2008) Situating world heritage sites in a multicultural society: the ideology of presentation at the Sacred City of Anuradhapura, Sri Lanka. Archaeol Postcolonial Crit, pp 177-195

Silva R (2000) Development of ancient cities in Sri Lanka with special reference to Anuradhapura. Reflect Herit Hist Scholarsh Pre-Mod, Sri Lanka, pp 49-81

Somasekaram T (1988) The national atlas of Sri Lanka. Sri Lanka Surv Dept, Colombo, Sri Lanka, pp $1-141$

Somasekaram T et al (1988) The national atlas of Sri Lanka. Surv Dep Sri Lanka, Colombo

Tennakoon MUA (2001) Evolution and role of small tanks cascade systems in relation to the traditional settlement pattern of the Rajarata. In: Proceedings of the workshop on food security and small tank systems in Sri Lank. National Science Foundation, Colombo, Sri Lanka, pp 64-78

Thiranagama S (2011) In my mother's house: civil war in Sri Lanka. University of Pennsylvania Press, Philadelphia

Viviano PA (1999) Source criticism. In: McKenzie SL, Haynes SR (eds) Each its own mean. Westminster John Knox, Louisville, pp 35-57

Wagalawatta T, Bebermeier W, Knitter D, Kohlmeyer K, Schütt B (2015) Ancient rock quarries in Anuradhapura, Sri Lanka. ETopoi J Anc Stud 4:45-65

Weisshaar H-J (2007) The citadel of Tissamaharama and the torrents of Spring. South Asian Archaeol

Wenham D (1979) Source criticism. In: Howard Marshall I (ed) New testament interpretation: essays on principles and method. Grand Rapids, Eerdmans

Wickremasinghe DMDS (1928) Epigraphia Zeylanica, vol 2. Published for the Government of Ceylon by Humphrey Milford, London

Wickremasinghe DDZ, Codrington HW (1933) Epigraphia Zeylanica, vol III, 1928-1933. Oxford

Wijesekara N (1990) Inscriptions. Archaeological Department Centenary commemorative series. Department of Archaeology Sri Lanka, Colombo

Withanachchi C (2013) Socio archaeological identification of ancient hydraulic civilization in Sri Lanka. J Archaeol Herit Manag Rajarata Univ Sri Lanka, 1

Withanachchi CR (2014) Dry zonal irrigation of Sri Lanka; lessons to the world for the sustainable development

Wittfogel KA (1959) Oriental despotism: a comparative study of total power. Yale University Press, New Haven

Publisher's Note Springer Nature remains neutral with regard to jurisdictional claims in published maps and institutional affiliations. 
Nuwan Abeywardana is currently a doctoral candidate at the Institute of Physical Geography, Freie Universität, Berlin focused on ancient dry zone hydraulic landscape of Sri Lanka. He has a M.Sc. in GIS and Remote Sensing (2008) and B.A. Special in Archaeology (2005) from the University of Peradeniya, Sri Lanka.

HMTGA Pitawala is a Professor of the Department of Geology, Faculty of Science, University of Peradeniya, Peradeniya, Sri Lanka. His research on petrogenesis, geochemistry and weathering of carbonates and other igneous rocks, origin of hydrothermal deposits of Sri Lanka, geoarchaeology and provenance of stream, tsunami and gem sediments of Sri Lanka.

Brigitta Schütt Dr. phil. (Aachen 1993), Habilitation (Trier 1998), has been a professor at the Institute of Geographical Sciences, Freie Universität Berlin since 2002, and served as Vice President for Research at Freie Universität Berlin since 2010. Research interests: past and present soil erosion, Late-Quaternary palaeoenvironments, palaeohydrology, past and present morphodynamics, drylands and watershed management.

Wiebke Bebermeier Dr. rer.nat. (Göttingen 2008) joined the Institute of Geographical Sciences in 2008 as a postdoctoral fellow; she has been a junior professor for physical geography with a focal point in landscape archaeology since 2011. Research interests: (pre)historic human environmental interactions, present and ancient watershed management and landscape archaeology.

\section{Affiliations}

\section{Nuwan Abeywardana ${ }^{1}$ (D) H. M. T. G. A. Pitawala ${ }^{2} \cdot$ Brigitta Schütt $^{1}$. Wiebke Bebermeier ${ }^{1}$}

H. M. T. G. A. Pitawala

apitawala@pdn.ac.lk

Brigitta Schütt

brigitta.schuett@fu-berlin.de

Wiebke Bebermeier

wiebke.bebermeier@fu-berlin.de

1 Physical Geography, Department of Earth Sciences, Freie Universität Berlin, Malteserstraße 74-100, 12249 Berlin, Germany

2 Department of Geology, University of Peradeniya, Peradeniya 20400, Sri Lanka 